\title{
定期点検結果を用いた既存コンクリート桁の 劣化速度に影響を与える環境要因分析
}

\author{
南 貴大 ${ }^{1}$ 藤生 慎 2 中山 晶一朗 3 - 高山 純一 4 \\ 1学生会員 金沢大学大学院 自然科学研究科環境デザイン学専攻（†920-1192 石川県金沢市角間町） \\ E-mail: takahoro1993@gmail.com \\ 2正会員 金沢大学助教 理工研究域環境デザイン学系（†920-1192 石川県金沢市角間町） \\ E-mail: fujiu@se.kanazawa-u.ac.jp \\ 3正会員 金沢大学教授＼cjkstart理工研究域環境デザイン学系（†920-1192 石川県金沢市角間町） \\ E-mail: nakayama@staff.kanazawa-u.ac.jp \\ 4フェロー 金沢大学教授 理工研究域環境デザイン学系（†920-1192 石川県金沢市角間町） \\ E-mail: takayama@staff.kanazawa-u.ac.jp
}

\begin{abstract}
高度経済成長期に一斉に建設された橋梁が耐用年数を迎え，架け替えや長寿命化の検討がなされている. このような中，自治体では 5 年に1度の頻度で定期点検を行うことで予防保全的な維持管理を目指している. しかし維持管理で扱う予算には限りがあるため, 補修の優先度を決定する必要がある. 橋梁が置かれてい る環境条件は異なっているため, 健全度の低下速度が異なる可能性がある. 既存の補修の優先度決定手法 には健全度と重要度のみを考慮して環境要因が考慮されていないものが少なくない. 本研究では, 石川県 が管理する橋梁のうち供用年数 20 年以上のコンクリート桁を対象とし, 数量化理論I類を用いて劣化に影 響を与える環境要因について分析を行った。 その結果, 供用年数によって劣化速度や劣化速度に影響を与 える要因が異なることが分かった。
\end{abstract}

Key Words : bridge, maintenance, regular inspection, natural environments, deterioration rate

\section{1. はじめに}

日本では高度経済成長期以降に整備したインフラが今 後一斉に老朽化し, 今後 20 年間で建設後 50 年以上経過 する施設の割合が加速的に高くなることが予測される. 橋長 $2 \mathrm{~m}$ 以上の道路橋は約 70 万橋あり，そのうち建設 年度不明橋梁 30 万橋を除いた約 40 万橋の道路橋におい て，建設後 50 年以上を経過する橋梁の割合は平成 25 年 3 月では約 $18 \%$ であるのに対し，10 年後には約 $43 \%$, 20 年後には約 $67 \%$ に急増する ${ }^{1)}$.このように一斎に老朽 化する橋梁を戦略的に維持管理する必要があると考えら れる.このような中，自治体では橋梁の定期的な点検を 行うことで事後保全的な維持管理から予防保全的な維持 管理に転換し，既存の橋梁を長持ちさせるという長寿命 化を図っている，そのため定期点検において橋梁の損傷 状況を把握，記録し，その情報によって必要な修繥・更 新を実施している。しかし予算には限りがあるため, 補 修の優先度を決定する必要がある. 補修の優先度の決定
について損傷の状況（健全度）と橋梁の重要度を考慮し て行われている自治体が少なくない，石川県が管理する 橋梁においては, 各部材の健全度から橋梁全体の橋梁健 全度指標 BHI（Bridge Health Index）が算出されている. BHI は定量的な指標として, 各部材の健全度と部材間の 重み係数を用いて加重平均法によって計算される. 橋梁 の重要度については, 路線の重要度及び交通量を総合評 価した指標である橋梁重要度指標 BPI（Bridge Public Index）によって評価される. BPI は路線の重要度（緊急 輸送道路, 跨線橋・跨道橋) と交通量 (交通種別) に着 目し，それぞれに重み係数を設定し，加重平均法によっ て算出する. これらの 2 つの指標 BHI と BPI の合成值に よって橋梁保全更新の優先度 P (Priority) が決定されて いる.

しかし，これらの補修の優先度決定手法には各橋梁が 置かれている環境条件が考慮されていない. 環境条件が 異なる橋梁では, 劣化の進行速度が大きく異なることが 予想される，そのため環境条件を考慮しない維持管理で 
あると, 劣化の進行速度を考慮した適切な補修の優先度 決定を行うことができない，そこで本研究では，過去 2 回分の橋梁定期点検結果を用いて，コンクリート桁の健 全度に影響を与える環境要因について統計的に分析する。

\section{2. 既往研究と本研究の位置づけ}

これまでに橋梁定期点検結果を用いた研究は数多く行 われているため, 既往研究をまとめるとともに本研究の 位置づけを行う。

過去の目視点検結果を用いた統計的な劣化予測モデル の構築は, 橋梁群全体としてのマネジメント戦略や予算 管理を検討寸る場合に必要であるため，多くの研究がな されている.

貝戸らは，NY市がここ9年間に実施した829橋梁に対 する目視点検結果を用いて劣化速度に着目することで, 過去の検査・補修等の情報が不十分な既存の構造物に対 しても適応可能であることを示し，マルコフ過程による 個別の橋梁の劣化予測を提案している2).また劣化速度 の過分散が施設グループ間における劣化速度の異質性と, グループを構成する個々の施設間における異質性という 2つの異なる異質性が混合されることによって発生する と考え，階層的異質性を考慮した混合マルコフ劣化八ザ ードモデルを定式化し，そのベイズ推計法を提案してい $3^{3)}$.

津田らは健全度間の推移過程を指数ハザードモデルを 用いて表現することで構造特性や使用環境，検查状況が 異なる異質な検査データを用いて劣化特性を非集計的に 推定することを可能としている ${ }^{4}$. また劣化予測モデル の推計精度を逐次改良するために新しく利用可能となっ た点検データに基づいてベイズ推計する方法論の提案も 行っている5.

小林らは健全度の測定結果に誤差が発生するメカニズ ムを隠れマルコフ劣化モデルを用いて表現できることを 示し, 真の健全度により定義されるマルコフモデルをマ ルコフ連鎖モンテカルロシミュレーションによりベイズ 推計する方法論を提案している9. また互いに双方の劣 化過程に影響を及ぼすような複合的劣化過程を表現する ために複合的マルコフ劣化モデルの開発を行い，さらに 調查情報が同時に獲得できないという時間的不整合性の 問題に関して, システム的なデータ久損を考慮した複合 的隠れマルコフ劣化モデルの提案を行っている゙.

また本研究と同様に橋梁定期点検結果を用いて統計的 分析から劣化要因の検討を行った研究もある.

玉越ら ${ }^{81}$ は，国が管理する全国の道路橋の定期点検結 果を用いて，重回帰分析により環境条件や橋梁形式，適 用基準など多岐にわたる属性との関連に着目して劣化に 支配的な要因の抽出を行っている.
大竹ら 9 は，岐阜県が管理する鋼橋RC床版の点検結果 を用いて主成分分析を行い, 離散量として与えられた従 来の健全度を連続量として評価し，算出した指標を目的 変数, 橋梁の台帳データベースに記載されている橋梁諸 元や環境条件を説明変数とし線形重回帰分析を用いて影 響因子の抽出を行っている.

大島ら ${ }^{10} は ，$ 橋梁の老朽化に影響寸る諸因子を解析し， 数量化理論I類を用いて, それらと部材損傷との関係に ついて検討を行い，各因子が部材損傷に影響する関係を 把握している.

また著者ら ${ }^{11)}$ も地方自治体の2期分の橋梁の定期点検 結果を用いて劣化速度を算出し, GISを活用して橋梁台 帳に記載されていない環境条件を把握し, 数量化理論 $\mathrm{I}$ 類を用いて環境要因と橋梁の諸元（橋長, 上部工材料, 供用年数）が健全度に与える影響を分析している. 分析 結果によると, 橋梁の諸元（橋長, 上部工材料, 供用年 数）が劣化速度に大きな影響を与える要因であることが 分かった.

以上のように，様々なデータ・方法を用いて，橋梁の 劣化に影響を与える諸因子の分析は数多くなされている. その結果, 橋梁の劣化において, 橋梁の諸元に比べて, 環境条件の影響は比較的小さいことが分かっている8，11). そこで本研究では，「橋梁の諸元」と「環境条件」を比

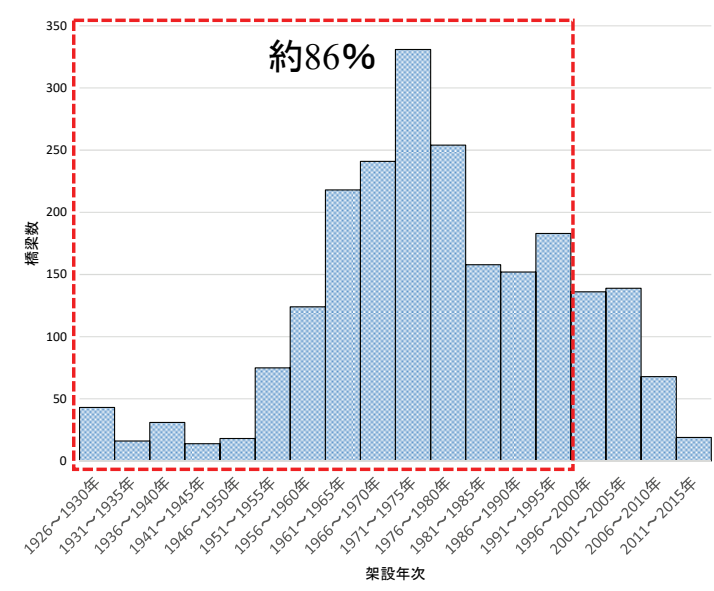

図-1 石川県における架設年次別の橋梁数

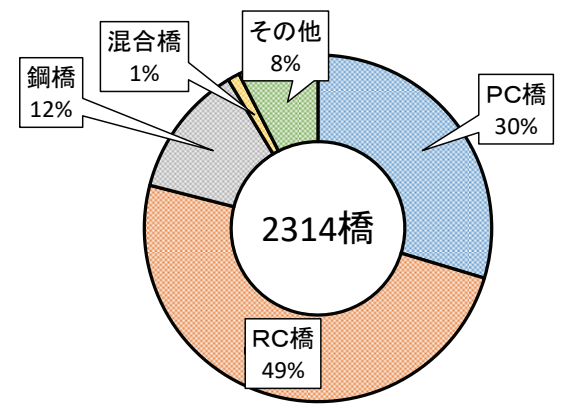

図-2 石川県が管理する橋梁における材料種別割合 
表-1＼cjkstart石川県における橋梁定期点検の一例

\begin{tabular}{|c|c|c|c|c|c|c|c|c|c|c|c|c|c|c|c|c|c|}
\hline 橋梁名 & 緊急輸送道路 & 上部工材料 & 架設年次 & 橋長 & 日交通量 & 大型車日交通量 & 主桁健全度 & 床版健全度 & 下部工健全度 & 支承健全度 & 伸縮装置健全度 & 橋面工健全度 & \begin{tabular}{|l|} 
BHI \\
\end{tabular} & BPI & $P$ & 緯度 & 経度 \\
\hline A & 第2次緊急輸送道路 & RC橋 & 1977 & 3.1 & 7300 & 328 & 5 & 3 & 3 & 5 & 5 & 5 & \begin{tabular}{|l|}
74 \\
\end{tabular} & 55 & 37.6 & 36.374 & 136.581 \\
\hline B & 第2次緊急輸送道路 & RC橋 & 1976 & 3.6 & 7300 & 328 & 5 & 5 & 5 & 5 & 5 & 5 & 100 & 45 & 18 & 36.374 & 136.581 \\
\hline $\mathrm{C}$ & 第2次緊急輸送道路 & RC橋 & 1975 & 4 & 7300 & 328 & 5 & 5 & 4 & 5 & 5 & 5 & 90.5 & 45 & 23.7 & 36.372 & 136.581 \\
\hline $\mathrm{D}$ & 第2次緊急輸送道路 & RC橋 & 1975 & 7 & 7300 & 328 & 5 & 4 & 5 & 5 & 5 & 5 & 96.5 & \begin{tabular}{|l|l|}
45 \\
\end{tabular} & 20.1 & 36.372 & 136.580 \\
\hline$E$ & 第2次緊急輸送道路 & RC橋 & 1975 & 7 & 7300 & 328 & 5 & 5 & 4 & 5 & 5 & 5 & 90.5 & \begin{tabular}{|l|}
45 \\
\end{tabular} & 23.7 & 36.580 & 136.577 \\
\hline $\mathrm{F}$ & 第2次緊急輸送道路 & RC橋 & 1975 & 4.8 & 7300 & 328 & 5 & 4 & 4 & 5 & 5 & 4 & \begin{tabular}{|l|}
86 \\
\end{tabular} & \begin{tabular}{|c|}
45 \\
\end{tabular} & 26.4 & 36.372 & 136.578 \\
\hline$G$ & 第2次緊急輸送道路 & RC橋 & 1973 & 9.5 & 7300 & 328 & 5 & 4 & 4 & 5 & 5 & 3 & 85 & 45 & \begin{tabular}{|l|}
2.7 \\
\end{tabular} & 36.370 & 136.575 \\
\hline $\mathrm{H}$ & 第2次緊急輸送道路 & RC橋 & 1973 & 3 & 7300 & 328 & 5 & 5 & 4 & 5 & 5 & 3 & \begin{tabular}{|l|}
88.5 \\
\end{tabular} & \begin{tabular}{|l|}
45 \\
\end{tabular} & 24.9 & \begin{tabular}{|l|l|}
36.370 \\
\end{tabular} & 136.575 \\
\hline I & 第2次緊急輸送道路 & RC橋 & 1974 & \begin{tabular}{|c|}
10.6 \\
\end{tabular} & 7300 & 328 & 5 & $\frac{5}{4}$ & $\frac{7}{4}$ & 5 & 3 & $\frac{5}{3}$ & \begin{tabular}{|l|l|}
82.0 \\
\end{tabular} & 45 & 28.8 & 36.370 & 136.575 \\
\hline $\mathrm{J}$ & 第2次緊急輸送道路 & RC橋 & 1974 & 10.6 & 7300 & 328 & 5 & 4 & 4 & 5 & 5 & 3 & 85 & 45 & 27 & 36.370 & 136.575 \\
\hline $\mathrm{K}$ & 第2次緊急輸送道路 & RC橋 & 1957 & 4.2 & 7326 & 725 & 3 & 5 & 3 & 5 & 5 & 5 & 62 & 55 & \begin{tabular}{|l|l|}
44.8 & \\
\end{tabular} & 36.374 & 136.566 \\
\hline $\mathrm{L}$ & 第2次緊急輸送道路 & RC橋 & 1968 & 17.7 & 7326 & 725 & 3 & 5 & 3 & 5 & 3 & 5 & 59 & 55 & 46.6 & 36.375 & 136.553 \\
\hline$M$ & 第2次緊急輸送道路 & RC橋 & 1966 & 18.6 & 7326 & 725 & 3 & 3 & 4 & 5 & 4 & 5 & 63 & 55 & \begin{tabular}{|c|}
44.2 \\
\end{tabular} & 36.375 & 136.553 \\
\hline $\mathrm{N}$ & 第2次緊急輸送道路 & RC橋 & 1986 & 7 & 7326 & 725 & 3 & 5 & 5 & 5 & 4 & 5 & 79.5 & 55 & \begin{tabular}{|c|}
34.3 \\
\end{tabular} & 36.374 & 136.547 \\
\hline 0 & 第2次緊急輸送道路 & PC橋 & 1970 & 93 & 7300 & 328 & 5 & 3 & 4 & 4 & 5 & 4 & \begin{tabular}{|c|}
81 \\
\end{tabular} & 45 & 29.4 & 36.397 & 136.517 \\
\hline $\mathrm{P}$ & 第2次緊急輸送道路 & 鋼橋 & 1997 & 83 & 0 & 0 & $\frac{5}{3}$ & $\frac{5}{4}$ & $\frac{4}{4}$ & 5 & 4 & 4 & \begin{tabular}{|l|}
65.5 \\
\end{tabular} & 45 & \begin{tabular}{|l|}
28.4 \\
38.7 \\
\end{tabular} & \begin{tabular}{|l|}
36.397 \\
\end{tabular} & 136.517 \\
\hline$Q$ & 第2次緊急輸送道路 & その他 & 1996 & 5 & 7326 & 725 & 5 & 3 & 3 & 5 & 5 & 5 & \begin{tabular}{|l|}
74 \\
\end{tabular} & 55 & \begin{tabular}{|l|}
37.6 \\
\end{tabular} & 36.391 & 136.517 \\
\hline$\frac{Q}{R}$ & 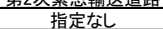 & 鋼橋 & 2000 & $\frac{.5}{17.5}$ & $\frac{1020}{100}$ & $\frac{120}{10}$ & $\frac{5}{5}$ & $\frac{5}{5}$ & $\frac{5}{5}$ & $\frac{5}{5}$ & $\frac{5}{5}$ & $\frac{5}{5}$ & \begin{tabular}{|l|}
100 \\
100
\end{tabular} & \begin{tabular}{|l|l|l|}
35 \\
\end{tabular} & \begin{tabular}{|l|l|}
14 \\
\end{tabular} & \begin{tabular}{|l|}
36.172 \\
\end{tabular} & 136.524 \\
\hline $\mathrm{s}$ & 指定なし & 鋼橋 & 1998 & 12.5 & 100 & 10 & 4 & 5 & 4 & 5 & 5 & 4 & \begin{tabular}{|l|}
80 \\
\end{tabular} & 35 & 26 & 36.177 & 136.521 \\
\hline$T$ & 指定なし & 鋼橋 & 1995 & 10.5 & 100 & 10 & 4 & 5 & 4 & 4 & 4 & 4 & 78.5 & \begin{tabular}{|l|}
35 \\
\end{tabular} & 26.9 & 36.180 & 136.524 \\
\hline$u$ & 指定なし & 鋼橋 & 1983 & 31 & 100 & 10 & 4 & 4 & 4 & 4 & 5 & 5 & 76 & 35 & 28.4 & 36.186 & 136.523 \\
\hline $\mathrm{V}$ & 指定なし & RC橋 & 1970 & 4.6 & 100 & 10 & 5 & 5 & 3 & 5 & 5 & 4 & \begin{tabular}{|l|l|}
80 \\
\end{tabular} & \begin{tabular}{|l|l|}
35 \\
\end{tabular} & \begin{tabular}{|l|}
26 \\
\end{tabular} & \begin{tabular}{|l|}
36.191 \\
\end{tabular} & 136.525 \\
\hline$w$ & 指定なし & RC橋 & 1964 & 2.8 & 100 & 10 & $\frac{5}{4}$ & $\frac{5}{5}$ & $\frac{5}{3}$ & 5 & $\frac{5}{5}$ & $\frac{4}{5}$ & \begin{tabular}{|l|}
71.5 \\
\end{tabular} & \begin{tabular}{|l|}
35 \\
\end{tabular} & \begin{tabular}{|l|}
31.1 \\
\end{tabular} & \begin{tabular}{|l|}
36.191 \\
\end{tabular} & 136.526 \\
\hline$x$ & 指定なよ & RC橋 & 1957 & 4.8 & 100 & 10 & 4 & 5 & 3 & 5 & 5 & 4 & 70.5 & 35 & 31.7 & 36.192 & 136.526 \\
\hline$\hat{\mathrm{Y}}$ & 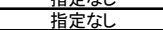 & $\mathrm{RC}$ 橋 & 1956 & 2.0 & 100 & 10 & $\frac{4}{5}$ & 5 & 3 & 5 & 5 & $\frac{4}{5}$ & \begin{tabular}{|c|}
10.0 \\
\end{tabular} & 35 & \begin{tabular}{|l|}
3.1 \\
25.4 \\
\end{tabular} & \begin{tabular}{|l|}
0.192 \\
36.196 \\
\end{tabular} & $\begin{array}{l}150.020 \\
36.525 \\
\end{array}$ \\
\hline$z$ & 指定なし & RC橋 & 1964 & 6.8 & 100 & 10 & 5 & 5 & 4 & 5 & 5 & $\frac{5}{2}$ & \begin{tabular}{|l|}
87.5 \\
\end{tabular} & 35 & 21.5 & \begin{tabular}{|l|}
36.204 \\
\end{tabular} & 136.525 \\
\hline AA & 指定なし & 鋼橋 & 1973 & 36 & 100 & 10 & 4 & 3 & 4 & 3 & 5 & 4 & $\begin{array}{l}70 \\
\end{array}$ & \begin{tabular}{|l|}
35 \\
\end{tabular} & \begin{tabular}{|l|}
32.0 \\
\end{tabular} & \begin{tabular}{|l|l|}
36.217 \\
\end{tabular} & $\begin{array}{l}136.530 \\
36.530\end{array}$ \\
\hline$A B$ & 指定なし & PC橋 & 1970 & 10 & 100 & 10 & 4 & 4 & 3 & 3 & 4 & 4 & 64 & \begin{tabular}{|l|}
35 \\
\end{tabular} & \begin{tabular}{|l|}
35.6 \\
\end{tabular} & 36.222 & 136.532 \\
\hline$A C$ & 指定なし & 鋼橋 & 1972 & 20 & 100 & 10 & 4 & 4 & 3 & 4 & 4 & 4 & $\begin{array}{l}65.5 \\
\end{array}$ & 35 & \begin{tabular}{|l|}
34.7 \\
\end{tabular} & 36.227 & 136.530 \\
\hline$A D$ & 指定なし & 鋼橋 & 1971 & 58 & 100 & 10 & $\frac{4}{4}$ & $\frac{4}{4}$ & $\frac{5}{3}$ & $\frac{4}{4}$ & $\frac{4}{4}$ & $\frac{4}{4}$ & \begin{tabular}{|l|}
65.5 \\
\end{tabular} & \begin{tabular}{|l|}
35 \\
\end{tabular} & \begin{tabular}{|l|}
34.7 \\
\end{tabular} & \begin{tabular}{|l|l|}
36.229 \\
\end{tabular} & $\begin{array}{l}136.5000 \\
36.532\end{array}$ \\
\hline $\mathrm{AE}$ & 指定なし & RC橋 & 1963 & \begin{tabular}{|l|}
19.1 \\
\end{tabular} & 100 & 10 & 5 & 5 & 4 & 5 & 4 & 4 & \begin{tabular}{|c|}
88.8 \\
\end{tabular} & \begin{tabular}{|l|}
35 \\
\end{tabular} & \begin{tabular}{|l|}
21.2 \\
\end{tabular} & \begin{tabular}{|l|}
36.247 \\
\end{tabular} & 136.537 \\
\hline $\begin{array}{l}\mathrm{A} L \\
\mathrm{AF}\end{array}$ & 指定なし & RC橋 & 1959 & \begin{tabular}{|l}
1.1 \\
22
\end{tabular} & 100 & 10 & 5 & 5 & $\frac{4}{4}$ & 5 & $\frac{4}{5}$ & 5 & \begin{tabular}{|l|}
90 \\
90.5 \\
\end{tabular} & \begin{tabular}{|l|}
35 \\
35
\end{tabular} & \begin{tabular}{|l|}
2.2 \\
19.7 \\
\end{tabular} & \begin{tabular}{|l|}
0.247 \\
36.251 \\
\end{tabular} & \begin{tabular}{|l|l|}
136.5319 \\
\end{tabular} \\
\hline$A G$ & 指定なし & RC橋 & 1990 & 7.5 & 100 & 10 & 5 & 5 & 4 & 5 & 5 & 4 & \begin{tabular}{|l|}
89.5 \\
\end{tabular} & \begin{tabular}{|l|}
35 \\
\end{tabular} & \begin{tabular}{|l|l|}
20.3 \\
\end{tabular} & \begin{tabular}{|l|l|}
36.251 \\
\end{tabular} & 136.539 \\
\hline $\mathrm{AH}$ & 指定なL & RC橋 & 1965 & 6.1 & 100 & 10 & 5 & 5 & 4 & 5 & 5 & 5 & \begin{tabular}{|l|}
90.5 \\
\end{tabular} & \begin{tabular}{|l|}
35 \\
\end{tabular} & \begin{tabular}{|l|}
19.7 \\
\end{tabular} & \begin{tabular}{|l|l|}
36.256 \\
\end{tabular} & 136.538 \\
\hline $\mathrm{AI}$ & 指定なし & RC橋 & 1966 & 6 & 100 & 10 & 4 & 5 & 5 & 5 & 5 & 5 & \begin{tabular}{|l|l|}
90.5 \\
\end{tabular} & \begin{tabular}{|l|}
35 \\
\end{tabular} & \begin{tabular}{|l|l|}
19.7 \\
\end{tabular} & \begin{tabular}{|l}
36.256 \\
\end{tabular} & 136.538 \\
\hline AJ & 指定なし & RC橋 & 1957 & 3 & 100 & 10 & 4 & 5 & 3 & 5 & 5 & 4 & \begin{tabular}{|l|}
70.5 \\
\end{tabular} & 35 & 31.7 & \begin{tabular}{|l|}
36.251 \\
\end{tabular} & 136.539 \\
\hline AK & 指定なし & RC橋 & 1960 & 2.8 & 100 & 10 & 3 & 5 & 5 & 5 & 5 & 3 & \begin{tabular}{|l|}
79.0 \\
\end{tabular} & \begin{tabular}{|l|}
35 \\
35
\end{tabular} & \begin{tabular}{|l|}
26.6 \\
\end{tabular} & \begin{tabular}{|l|}
36.251 \\
\end{tabular} & \begin{tabular}{|l}
130.053 \\
36.539
\end{tabular} \\
\hline $\mathrm{AL}$ & 指定なし & RC橋 & 1957 & 2.5 & 100 & 10 & 5 & 5 & 3 & 5 & 5 & 2 & \begin{tabular}{|l|}
78 \\
\end{tabular} & 35 & \begin{tabular}{|l|}
27.2 \\
\end{tabular} & \begin{tabular}{|l|}
36.301 \\
\end{tabular} & 136.534 \\
\hline
\end{tabular}

表-2＼cjkstart石川県における橋梁の健全度の評価基準

\begin{tabular}{|c|l|}
\hline 健全度 & \multicolumn{1}{|c|}{ 損傷状況 } \\
\hline 5 & 劣化·損傷が認められない \\
\hline 4 & 些細な劣化·損傷のみで, 点検記録を継続する \\
\hline 3 & 軽度の劣化·損傷があり, 計画的に維持管理補修を行う \\
\hline 2 & 重度の劣化·損傷があり, 早急な補修対策が必要 \\
\hline 1 & 甚大な損傷で安全確保に支障をきたす(通行止め) \\
\hline
\end{tabular}

較するのではなく，劣化に大きな影響を与えている諸元 でグルーピングし，環境要因分析を行うことで，諸元に よって環境条件が橋梁の劣化に与える影響の程度が異な るのかについて定量的に明らかすることを目的とする.

予算に制約がある中，数多くの橋梁を管理する自治体 において, 諸元に応じた劣化速度に影響を与える環境要 因を把握することで，より効率的かつ効果的な維持管理 計画の策定支援が可能になる.

\section{3. 使用データ}

石川県の架設年次別の橋梁数を図-1に示す. 石川県が 管理する橋梁約 2314 橋のうち供用年数が 20 年以上の橋梁 は平成28年で約 $86 \%$ を占めており，今後加速的に高齢化 することが予想される. また図-2に示すように石川県が 管理する橋梁のうち約 $80 \%$ はコンクリート橋であり，コ ンクリート橋の対策を講じることの影響は大きいと考え る. そこで本研究では石川県が管理する橋梁のうち供用 年数が 20 年以上のコンクリート橋を対象に健全度に影響 を与えている環境要因について分析を行った．石川県は 日本海に面しており冬の気象特性に起因する飛来塩分,
山岳部を中心に冬季交通を確保するための凍結防止剂の 散布，交通量の多い都市部における通行車両の重量や衝 撃などによる疲労など，劣悪な環境下にさらされている。 このように劣化に影響を与えうる環境要因が多様である 石川県における環境要因分析は効率的な維持管理を行う 上で有用であると考える.

\section{（1）石川県における橋梁定期点検データ}

石川県の橋梁定期点検では点検結果だけでなく表-1に 示すように架設年次，上部工の材料，径間数，橋長，幅 員，最大支間長，道路交通センサス結果（日交通量・大 型車日交通量）, 所在地, 緯度経度などの橋梁の諸元も 記されている．定期点検は5年に1度の頻度で行われてお り点検項目としては主桁，床版，下部工，伸縮装置，支 承，橋面工を対象にしており，表-2に示すように損傷状 況に応じて損傷の見られない健全なものから5，4，3，2， 1と5段階で健全度が離散的に評価されている. また前述 したように，その点検結果と重要度によって補修・補強 の優先度が計算されている。

\section{（2）地理空間情報データ}

GISを活用し各橋梁が置かれている環境条件について 把握を行った，実際，橋梁は橋長と幅員があるため，ポ イントデータではなくポリラインデータで表すことがで きる，しかし橋梁定期点検データでは位置情報について 代表的なポイントで記載されている.ここでの橋梁の代 表的な位置情報というものは，橋梁を点検した点に相当 しており，必ずしも橋梁の中央点に相当するものではな い. 本研究では代表的な位置情報を橋梁の代表点として 
用いることとする.

本研究では, 地理空間情報として, 全国総合開発計画, 国土利用計画，国土形成計画などの国土計画の策定や推 進の支援のために国土に関する様々な情報を整備, 数值 化した「国土数值情報」を用いた 2 .

\section{a) 飛来塩分による影響}

海岸線近くに位置するコンクリート橋において塩分が 浸透し，内部の鋼材が腐食することでコンクリートがひ び割れ・剥離が生じる塩害が深刻化している ${ }^{13}$. 本研究 では国土数值情報の海岸線データを用いて, 風向きや風 力などを考慮せず，単純に海岸線からの距離を飛来塩分 の代替指標とすることとした.

\section{b) 凍結防止剂の散布による影響}

冬季における路面の走行安全性を確保するために土木 事務所ごとに凍結防止剤を散布している．そのため石川 県では凍結防止剂によって塩害による損傷を受けたコン クリート橋がみられ, 特に桁端部, 床版の張出部, 下部 工などに劣化が顕著にみられる ${ }^{14}$. 本研究では, 土木事 務所ごとに細かい記録の形式は異なるが，凍結防止剂を 散布した道路に色付けして記録している凍結防止剤散布 履歴マップを用いて散布の有無の把握を行った. しかし 散布量の記録は土木事務所によって記録が徹底されてい ないため, 凍結防止剤の量については国土数值情報の平 年メッシュにある年最深積雪量を指標として代替した.

\section{C) 交通量による影響}

自動車交通等による外力の繰り返しによって構造物に 損傷が累積され，コンクリート橋梁ではひび割れが主た る損傷となっている ${ }^{15}$. 疲労の原因として考えられる自 動車加重を考慮するため, 本研究では橋梁定期点検デー 夕に記載されている道路交通センサスの日交通量を指標 として用いることとした.

\section{d) 降水量による影響}

降水量が多いほど概ね付着塩分量は，減少する傾向に あることが知られている ${ }^{10}$.これは雨風による林の洗い 流しや飛来塩分自体の減少の影響であると考えられてい る. 一方, 降雨などによる高湿度環境下のコンクリート ではアルカリ骨材反応の原因であるゲルの吸水・膨張を 促進させることが知られている ${ }^{17}$. 本研究では国土数值 情報の平年值メッシュデータを用いた. 平年值メッシュ データとは降水量, 気温, 最深積雪, 日照時間, 全天日 射量の5種類の気象要素について, 過去30年間の観測地 から $1 \mathrm{~km}$ メシュ（3次メッシュ）ごとの平年值を算出 したものである，その中で降水量の年合計值である年降 水量を指標として用いることとした。

\section{e) 温度変化による影響}

コンクリート橋の温度分布は気象条件によって複雑に 変化し部材に温度差が生じると温度応力が発生すること が知られている ${ }^{18)}$. 本研究では温度の変化を考慮するた
め，国土数值情報の平年值メッシュデータを用いた．平 年值メッシュデータには月別の最高気温, 最低気温, 平 均気温の3種類の温度が記載されているが，年間を通し ての温度変化を考慮するため, 石川県で最も暑い月であ る8月の最高気温と最も寒い月である2月の最低気温のデ ータと年平均全天日射量のデータを用いることとした.

\section{f）標高による影響}

高い標高に位置する橋梁は標高が低い地域に比べ積雪 や降水，低気温など橋梁の健全度に影響しうる要因が数 多く存在する. 本研究では, 各橋梁が位置する地点の標 高として, 国土数值情報の標高・傾斜度 5 次メッシュデ ータの平均標高を用いることとした.

\section{4. 橋梁の劣化速度に影響を与える環境要因分析}

本章では環境要因が供用年数 20 年以上のコンクリート 桁の健全度に与える影響の程度について統計的に分析寸 る. 本研究では健全度にいたった損傷・劣化については, 記録が複雑であることから考慮せずに代替的な総合指標 である健全度のみを対象として分析を行った．前述した 通り, 石川県の橋梁定期点検では主桁, 床版, 下部工, 伸縮装置, 支承, 橋面工の6部材を点検対象部材として いるが，部材材料が明確である主桁を対象とした。

\section{（1）データ欠損を考慮した劣化指標}

石川県の橋梁定期点検では5年に1度の頻度で橋梁の損 傷程度を健全度として5段階で評価している．健全度は 点検時点の損傷状況を表しており, 点検以前の健全度の 変化に関する情報が含まれていない，補修・補強の記録 が欠損しているデータを用いる場合, 単に健全度を劣化 指標として用いることは過度に安全側に評価される可能 性があるため危険である. しかし近年では, 点検データ の記録が蓄積されており，石川県では2巡目の点検を終 えた橋梁が多く存在する，そこで本研究では健全度を劣 化指標として用いるのではなく，2回分の健全度を用い た指標を劣化指標とした。具体的には式(1)に示すよう に1巡目の定期点検から得られる健全度から 2 巡目の定期

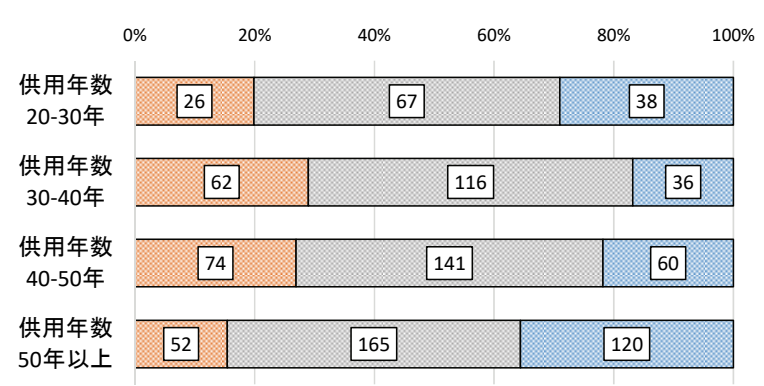

$$
\square \mathrm{v}>0 \quad \square \mathrm{v}=0 \quad \square \mathrm{v}<0
$$

図-3 コンクリート桁における供用年数別の劣化速度 
点検から得られる健全度の差を点検スパンで除したもの を劣化速度として定義した. 劣化速度を指標とすること で, 劣化速度が 0 より大きいとき通常劣化, 劣化速度が 0 のとき劣化なし, 劣化速度が0より小さいとき補修・補 強の可能性ありとして扱うことができる，そのため補 修・補強の記録が久損している石川県の橋梁定期点検デ 一タにおいても，劣化速度が0より小さい補修・補強の 可能性があるサンプルを除くことで実質的な劣化を把握 することができる．実際には，劣化速度が0より小さい サンプルは劣化が顕著であるサンプルであるため，除い て分析を行うと安全側に評価してしまう恐れがある。し かし本研究では補修履歷が久損しているデータを扱うた め, 健全度が回復したサンプルの扱いは今後の課題とし, 劣化速度が0以上のサンプルのみを分析する. 図-3は各 部材における劣化速度別の橋梁数を示している. 供用年 数 50 年以上のコンクリート桁においては劣化速度が負で ある割合が比較的高く, 補修・補強がすでになされてい ることが分かる.

$$
v=\frac{s_{1}-s_{2}}{t_{2}-t_{1}}
$$

ここに, $\quad v ：$ 劣化速度

$s_{1}: 1$ 巡目点検結果の健全度

$s_{2}: 2$ 巡目点検結果の健全度

$t_{1}: 1$ 巡目の点検年次

$t_{2}: 2$ 巡目の点検年次

\section{(2) 分析手法}

コンクリート桁の健全度に影響を与える環境要因につ いて数量化類理論を用いて分析を行った．本研究では, 供用年数別にコンクリート桁を分類し，それぞれ劣化速 度を目的変数とし，水準に分類した環境要因を説明変数 とすることで数量化理論I類を適応している．環境要因 は量的データであり，質的データに変換することで情報 を減らしてしまうが，具体的な数值が解析にあまり影響 を受けなくなるため外れ值の影響を無視することができ るため本研究では数量化理論類を採用した.

\section{（3）環境要因の水準分け}

数量化理論I類における説明変数の水準とは各要因の 中のそれぞれの設定条件のことである. 設定条件には各 環境要因別に根拠となる基準を設定することが望ましい が, 各環境要因で根拠となる基準がないこと，また全国 の基淮值を基に水準を決定してしまうと，石川県が全国 の基準より特出している環境要因における水準のサンプ ル数の偏りが生じてしまうことを考慮して各環境要因で 各水準のサンプル数が等しくなるように5つの水準に分
類することとした．ただし凍結防止剤の散布は有無のデ 一タであるため, 散布ありと散布なしの2つの水準とし た．また海岸線からの距離については300m以内， $300 \mathrm{~m}$ $\sim 1 \mathrm{~km}, \quad 1 \mathrm{~km} \sim 3 \mathrm{~km}, 3 \mathrm{~km} \sim 10 \mathrm{~km}, 10 \mathrm{~km}$ 以上の5水準, 日 交通量につきましては1000台/日以下，1000～4000台/日， 4000〜10000台/日，10000〜20000台/日，20000台/日以上の 5水準に設定した. 水準数を少なくしてしまうと説明変 数間で相関がみられやすくなったため, 説明変数間の相 関が0.6未満となるように5水準に設定した。 そのため多 重共線性による回帰係数の符号が本来なるべきものと逆 の符号になるといった問題が発生する可能性は低いと考 えられる。

\section{5. 分析結果}

数量化理論類では説明変数の目的変数に対する貢献 度, つまり環境要因がコンクリート桁の劣化速度に与え る影響の程度をレンジとして評価される．また1つの環 境要因でに着目した場合に，どの水準がコンクリート桁 の劣化速度に与える影響度合いを定量的に表す指標とし てカテゴリースコアが算出される．本章ではコンクリー 卜桁の健全度に影響について環境要因について供用年数 別にみることで, 各段階で考慮すべき環境要因について 考察を行う.

まず, 数量化理論類によって得られた定数項（劣化 速度の平均）と各環境要因の影響度の合計值（レンジの 合計值），分析精度（重回帰係数）について表-3に示寸. 供用年数が経過するほど平均劣化速度が大きくなるこ とが想定されるが，供用年数 $30 \sim 40$ 年のコンクリート桁 の平均劣化速度が最も大きい結果となった. 理由として は図-3からもわかるように供用年数 50 年以上のコンクリ 一ト桁において健全度が回復しているサンプルの割合が 高く, 前述したように著しい劣化が起こっているサンプ ルを除いていることが考えられる。

レンジの合計は各環境要因が劣化速度に与える影響度 （レンジ）の和であり，環境要因を考慮することによる 劣化速度の変動度合いを表す指標として算出した. 供用 年数が経過するほどレンジの合計值は減少傾向にあるこ とから，比較的新しいコンクリート桁の方が環境要因の

表-3 数量化理論分析の結果

\begin{tabular}{|c|c|c|c|}
\hline & $\begin{array}{c}\text { 平均劣化速度 } \\
\text { (定数項 }\end{array}$ & レンジの合計 & 重回帰係数 \\
\hline $\begin{array}{c}\text { 供用年数 } \\
\text { 20-30年 }\end{array}$ & 0.057 & 1.082 & 0.631 \\
\hline $\begin{array}{c}\text { 散用年数 } \\
\text { 30-40年 }\end{array}$ & 0.088 & 0.938 & 0.467 \\
\hline $\begin{array}{l}\text { 供用年数 } \\
\text { 40-50年 }\end{array}$ & 0.078 & 0.677 & 0.478 \\
\hline $\begin{array}{l}\text { 供用年数 } \\
50 \text { 年以上 }\end{array}$ & 0.057 & 0.557 & 0.409 \\
\hline
\end{tabular}




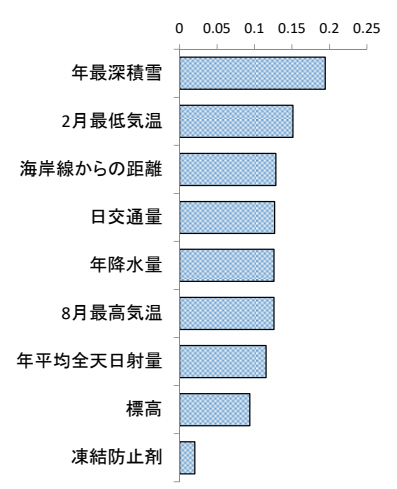

図-4 供用年数20～30年のコンクリート桁におけるレンジ

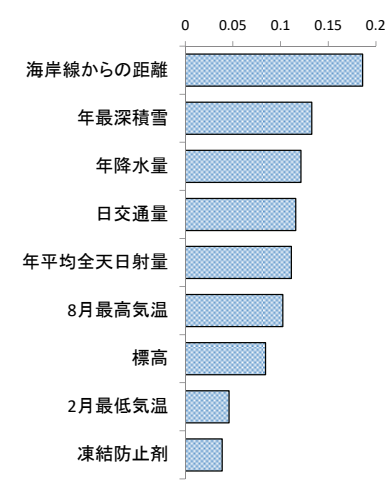

図-5 供用年数30４0年のコンクリート桁におけるレンジ

影響を受けやすいことが分かる.

分析の精度を表寸重回帰係数においては, 諸元（供用 年数，材料種別）の条件を合わせずに分析を行っている 既往研究 ${ }^{11} に$ に比べ，コンクリート桁に着目し供用年数別 に分類することで高い結果となっている．最も低い重回 帰係数であっても 0.4 以上あり, 橋梁の供用年数で対象 を限定することで，より精度よく劣化速度を再現するこ とが可能となっている.

次にコンクリート桁の劣化速度に影響を与えている環 境要因について供用年数別に考察する. 数量化理論類 によって得られたレンジを供用年数別に図-4, 図-5, 図-

6, 図-7に示寸. 図-4から供用年数が20〜30年のコンクリ 一ト桁の劣化速度には最も最深積雪量が影響度が大きく, 次に 2 月最低気温, 海岸線からの距離が影響を与えてい ることが分かる. 図-5から供用年数が30〜 40年のコンク リート桁の劣化速度に最も海岸線からの距離が影響を与 えており, 次に年最深積雪量, 年降水量が影響を与えて いることが分かる. 図-6から供用年数が $40 \sim 50$ 年のコン クリート桁の劣化速度に最も2月最低気温の影響が大き $<$, 次に日交通量, 年降水量の影響が大きいことが分か る. 図-7から供用年数が 50 年以上のコンクリート杵の劣 化速度に最も2月最低気温の影響が大きく，次に年降水 量, 年最深積雪量の影響を受けていることが分かる. 供 用年数によってコンクリート桁の劣化速度が影響を与え

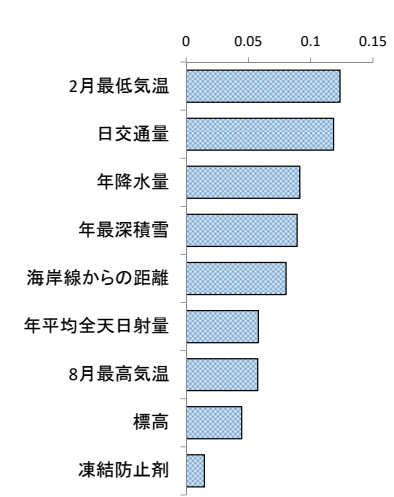

図-6 供用年数 40〜 50 年のコンクリート桁におけるレンジ

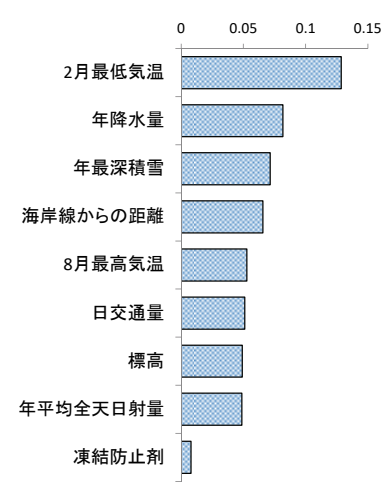

図-7 供用年数50年以上のコンクリート桁におけるレンジ

る環境要因は異なっていることがわかったため, 供用年 数に応じた環境要因対策が必要であることが示唆された。 次に供用年数別でコンクリート桁に影響を与えている 環境要因について各水準でごのような影響を与えている のかについてカテゴリースコアを用いて考察する. 本研 究では最もレンジが大きい環境要因について考察を行う。 数量化理論I類によって得られたカテゴリースコアを供 用年数別に図-8, 図-9, 図-10, 図-11に示す．図-8は供 用年数が $20 \sim 30$ 年のコンクリート桁の劣化速度に最も影 響与えている年最深積雪量のカテゴリースコアを示して いる. 積雪量が増加するほどカテゴリースコアが増加傾 向にあり, 積雪量が多いほど劣化しやすい傾向がみられ る. 積雪量が多い地域では冬季の凍結防止剤の散布量が 増加することが考えられる. 図-9は供用年数が30〜 40年 のコンクリート桁の劣化速度に最も影響与えている海岸 線からの距離のカテゴリースコアを示している．海岸線 からの距離が最も近い $300 \mathrm{~m}$ 以内の橋梁が最も飛来塩分 の影響を受けることが予想されるが，カテゴリースコア によると海岸線から $300 \mathrm{~m} 〜 1 \mathrm{~km}$ の距離に位置するコンク リート桁が最も劣化を速める影響を受けていることが分 かる. 原因としては海岸線から300m以内のコンクリー 卜桁はすでに塩害対策を行っていることが考えられるた め，対策が不十分である海岸線から $300 \mathrm{~m} \sim 1 \mathrm{~km}$ のコンク リート桁に影響を与えていることが考えられる. 図-10 


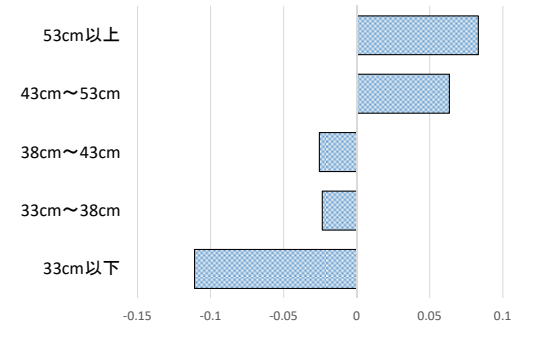

図-8＼cjkstart年最深積雪量におけるカテゴリースコア （供用年数 $20 \sim 30$ 年のコンクリート桁）

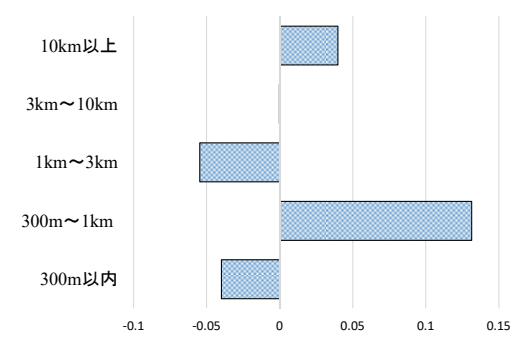

図-9＼cjkstart海岸線からの距離におけるカテゴリースコア （供用年数30～40年のコンクリート桁）

は供用年数が $40 〜 50$ 年のコンクリート桁の劣化速度に最 も影響与えている2月の最低気温のカテゴリースコアを 示している. 図-11は供用年数が50年以上のコンクリー 卜桁の劣化速度に最も影響与えている2月の最低気温の カテゴリースコアを示している. 供用年数が $40 \sim 50$ 年と 50 年以上のコンクリート桁において2月の最低気温が高 くなるほど劣化しや寸い傾向がみられる．2月の最低気 温が高い場合，年間の温度変化が小さいことが考えられ るため, 温度変化による劣化であることは考えにくい.

\section{6. まとめと今後の課題}

本研究では道路構造物の予防保全的な維持管理を行う 上で必要となる定期点検結果を用いて，石川県が管理す る橋梁のうち, 供用年数が 20 年以上のコンクリート桁の 健全度に影響を与えている環境要因について数量化理論 I類を用いて統計的に分析を行った，その結果，供用年 数によって劣化速度が異なること, 環境要因の影響の受 けや寸さが異なること, 影響を与える環境要因が異なる ことが分かった. そのため, 供用年数に応じた環境要因 対策を行うことが必要であり, 劣化速度への影響度が高 い環境要因に対しては補修の優先度を高くすることで予 防保全的維持管理を効率的かつ効果的に行うことが求め られる.

本研究では劣化指標である劣化速度を算出する際に単 純に健全度を間隔尺度として扱っているが，健全度間が 等間隔. 等距離であることは考えにくい. そのため今後 健全度間の間隔を考慮した劣化速度の算出が必要である。

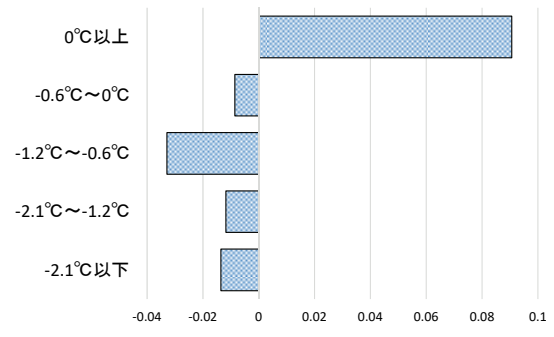

図-10 2月最低気温におけるカテゴリースコア （供用年数 40～50年のコンクリート桁）

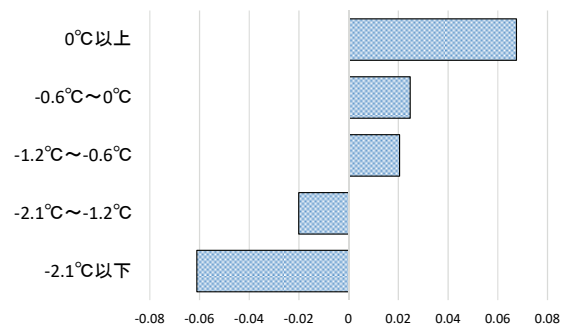

図-11 2月最低気温におけるカテゴリースコア (供用年数 50 年以上のコンクリート桁)

また本研究では, 石川県が管理する橋梁のみに着目し ているため各環境要因の水準設定の際, 橋梁の劣化に関 する根拠が不足している. 今後の課題として各環境要因 における水準について水準のパターンをいくつか設定し, 適切な水準の決定が必要である.

また定期点検は橋梁によって点検者が異なっている. したがって診断結果に点検者の経験やスキルによってば らつきが生じている ${ }^{18)}$. しかし本研究で取り扱うデータ では点検者の経験やスキルによるばらつきを取り除くこ とは難しい. そのため今後の課題として点検者の情報が 記載されているデータを用いた分析を行い，点検者の経 験やスキルの差による診断精度のばらつきを考慮するこ とが求められる.

補修の履歴は橋梁の劣化の速度に対して影響を与えて いると考えているが，本研究では補修の履歴が不十分で あったため考慮していない．前述しているが健全度が回 復しているデータの取り扱いが補修の履歴の有無で大き く変わる. 補修の履歴が不完全である場合どのようにし て補修の履歴を考慮するべきかについては補修履歴が残 っているデータを用いて健全度が回復していた原因を明 らかにする必要があり今後の検討課題とした.

また本研究では供用年数によってコンクリート桁に影 響を与えている環境要因が異なることは示されたが，異 なる理由については明らかにできていない，そのため今 後より詳細な分析を行い, 明らかにする必要がある.

\section{参考文献}

1) 国土交通白書 $\mathrm{H} 27$ 第 2 部第 2 節，http://www.mlit.go.jp /hakusyo/mlit/h27/hakusho/h28/pdf/np202000.pdf （ 2017 
年 1 月 10 日閲覧)

2) 貝戸清之，阿部允，藤野陽三 : 実測データに基づく 構造物の劣化予測, 土木学会論文集, No. 744, pp. 2938, 2003.

3) 貝戸清之, 小林潔司, 青木一也, 松岡弘大 : 混合マ ルコフ劣化ハザードモデルの階層ベイズ推計, 土木 学会論文集 D3, Vol. 68, No. 4, pp. 255-271, 2012.

4) 津田尚胤, 貝戸清之, 青木一也, 小林潔司：橋梁劣 化予測のためのマルコフ推移確率の推定, 土木学会 論文集，No. 801/I-73, pp. 69-82, 2005.

5) 津田尚扸, 貝戸清之, 山本浩司, 小林潔司：ワイブ ル劣化ハザードモデルのベイズ推計法 : 土木学会論 文集 F, Vol. 62, No. 3, pp. 473-491, 2006.

6) 小林潔司, 貝戸清之, 林秀和：測定誤差を考慮した 隠れマルコフ劣化モデル, 土木学会論文集 $\mathrm{D}$, Vol. 64, No. 3, pp. 493-512, 2008.9.

7) 小林潔司, 貝戸清之, 大井明, Nguyen Dinh THAO, 北浦直樹：データ欠損を考慮した複合的隠れマルコ フ舗装劣化モデルの推計, 土木学会論文集 E1, Vol. 71, No. 2, pp. 63-80, 2015.

8) 玉越隆史, 横井芳輝, 石尾真理 : 全国規模の点検デ ータに基づく道路橋のコンクリート部材の劣化の特 徵, コンクリート工学論文集, Vol. 25, pp. 167-180, 2014.

9) 大竹雄, 流石克, 小林孝一, 本城勇介 : 橋梁点検デ ータベースの統計解析に基づく劣化機構を考慮した 鋼橋 $\mathrm{RC}$ 床版の健全度評価, 土木学会論文集 $\mathrm{A} 1$ （構 造・地震工学），Vol. 68, No. 3, pp. 683-695, 2012.

10) 大島俊之, 三上修一, 山崎智之, 丹波郁恵 : 橋梁健 全度評価に用いる評価方法の検討と影響要因の解析, 土木学会論文集, No. 675, pp. 201-217, 2001.
11) 南貴大, 藤生慎, 中山晶一朗, 高山純一, 近田康 夫 : 環境要因が橋梁の健全度に与える影響の分析一 石川県の橋梁定期点検データを用いて一，土木学会 論文集 D3, Vol. 72, No. 5, pp. 251-260, 2016.

12）国土数值情報ダウンロードサービス, http://nlftp.mlit. go.jp/ksj/other/details.html（2016月 8 月 11 日閲覧）

13）国総研資料第 55 号，コンクリート橋の塩害対策資料 集一実態調査に基づくコンクリート橋の塩害対策の 検 討 - , http://www.nilim.go.jp/lab/bcg/siryou/tnn/ tnn0055.htm（2016月 8月 11 日閲覧）

14) 金沢大学 SIP : 塩害および ASR によるコンクリート 橋梁の劣化とメンテナンスマネジメント開発, http:// sip-hokuriku.com/wp-content/uploads/2015/04/lecture_ $1504201 . p d f （ 2016$ 年 8 月 11 日閲覧）

15) 国立研究開発法人土木研究所構造物メンテナンス研 究センターCAESAR, https://www.pwri.go.jp/caesar/ overview/02-04.html（2016年 8 月 13 日閲覧）

16) 既存耐候性橋梁の付着塩分量とさび厚に関する相関 分析, http://www.ubemachinery.co.jp/research/gijutu/ bridge/05.pdf（2016年 8 月 13 日閲覧）

17) 温度応力によるひび割れを防ぐ, http://www.beton.co. jp/pdf/books/115-tatchiyomi.pdf（2016 年 8 月 11 日閲 覧）

18）点検業務の IoT の利活用をめざして 自治体橋梁にお ける橋梁点検業務実態調查報告書【課題・ニーズ調 查偏】, http://www.socialinfra.org/p_activity/ questionnaire/Bridge_tenken_Digest.pdf（2017 年 7 月 8 日閲 覧）

(2017. 2. 24 受付)

\title{
ANALYSIS OF RELATIONSHIP BETWEEN DETERIORATION RATE OF CONCRETE GIRDER AND NATURAL ENVIRONMENTS USING INSPECTION DATA
}

\author{
Takahiro MINAMI, Makoto FUJIU, Shoichiro NAKAYAMA \\ and Jyunichi TAKAYAMA
}

Recently, the study of extending the service life of bridges has gained attention. Many bridges have been built during high economic-growth periods, and have reached their service life. Therefore, their rebuilding and the extending of their service life must be considered. Within this situation, local municipal governments are also conducting regular inspections once every five years as part of preventative maintenance, rather than performing corrective maintenance. In this study, we will shed light on which bridges are most prone to rapid deterioration by using data from the regular inspection of bridges. We will do this by calculating the deterioration rate from inspection data from two inspection cycles in order to determine the environmental factors that affect the deterioration rate. In regards to analysis methods, we used Hayashi's Quantification Method Type I to examine the level of influence each factor has on the deterioration rate of concrete girder. 